\title{
A PREPONDERÂNCIA DAS FRONTEIRAS GEOGRÁFICA E SIMBÓLICA NA TRANSNACIONALIZAÇÃO AFRO-RELIGIOSA NO PRATA
}

\author{
Daniel Francisco de Bem*
}

\author{
"Mude a atitude, não existem fronteiras na América Latina! (...) \\ Andamos por qualquer lugar!" (O Rappa)
}

\begin{abstract}
Resumo: Baseando-me numa revisão bibliográfica sobre o processo de transnacionalização religiosa afro-brasileira, desde o Rio Grande do Sul, para a Argentina e o Uruguai, e na minha experiência de campo sobre o mesmo tema, teço algumas considerações sobre os contatos dos pais-de-santo gaúchos com a primeira geração de argentinos e uruguaios convertidos, no processo que levou a linha cruzada para além das fronteiras do território brasileiro. Realço a importância das açōes religiosas na regiāo fronteiriça gaúcha para a constituição dessas redes transnacionais. Destaco também a constituição de uma fronteira identitária própria às religiōes afro-brasileiras frente às territorializaçôes dos estados-nação em questão, conformando um outro tipo de território, em competição com o nacional, o território afro-religioso transnacional.
\end{abstract}

Palavras-chave: religiōes afro-brasileiras; transnacionalização religiosa; fronteira geográfica; jogos identitários.

Abstract: This text allies bibliographic revision and fieldwork results in order to examine the processes of transnationalization of African-Brazilian religions from Rio Grande do Sul, the southernmost state of Brazil into Argentina and Uruguay. It focuses on the contacts of pais-de-santo from Rio Grande do Sul with the first generation of Argentineans and Uruguayans followers, in a process that spread linha-cruzada beyond Brazilian territory. Religious actions at the border are pointed as having great significance in the transnational networking. Identity boundaries between incoming African-Brazilian religions and the previous territorialization of these nation-states are established, resulting in a dispute involving national territory and a transnational African-Brazilian religious territoriality.

Keywords: African-Brazilian religions; religious transnationalization; geographic borders; identity role-playing.

* Doutorando em Antropologia Social (PPGAS/UFRGS) e bolsista CAPES.

Debates do NER, Porto Alegre, Ano 9, N. 13, P. 25-46, JAn./Jun. 2008 